\title{
Efonidipine improves renal function and decreases proteinuria in elderly hypertensive patients in the JATOS study
}

\author{
Takafumi Okura \\ Hypertension Research (2010) 33, 1112-1113; doi:10.1038/hr.2010.150; published online 2 September 2010
}

$\mathrm{C}$ hronic kidney disease (CKD) includes conditions that damage the kidneys and decrease their ability to maintain normal health. CKD may result in development of complications such as high blood pressure, anemia, weak bones, poor nutritional health and nerve damage. ${ }^{1}$ Kidney disease also increases the risk of developing cardiovascular diseas. $^{2-4}$

The two main causes of CKD are high blood pressure and diabetes, which are responsible for up to two-thirds of cases. Uncontrolled or poorly controlled diabetes or hypertension is a leading cause of heart attacks, strokes and $\mathrm{CKD}$. The guidelines for the management of hypertension 2009 of the Japanese Society of Hypertension $(2009)^{5}$ recommends using angiotensin-converting enzyme inhibitors (ACEIs) or angiotensin II receptor blocker as first line therapy in the treatment of hypertension. Patients with $\mathrm{CKD}$ usually require a combination of antihypertensive therapy to achieve the recommended blood pressure goal of $<130 / 80 \mathrm{~mm} \mathrm{Hg}$. Japanese Society of Hypertension (2009) recommends using a $\mathrm{Ca}$ channel blocker (CCB) or diuretic as second line antihypertensive therapy. However, it still remains unclear which agent is more effective for reducing the progression of renal insufficiency in CKD patients.

Recent subanalysis of renal outcome data in the Avoiding Cardiovascular Events through Combination Therapy in Patients Living with Systolic Hypertension trial ${ }^{6}$ showed that combination therapy of an

\footnotetext{
T Okura is at the Department of Integrated Medicine and Informatics, Ehime University Graduate School of Medicine, Toon City, Ehime 791-0295, Japan.

E-mail: okura@m.ehime-u.ac.jp
}

ACEI (benazepril) plus CCB (amlodipine) slowed progression of nephropathy (doubling of serum creatinine, estimated glomerular filtration rate $(\mathrm{eGFR})<15 \mathrm{ml} / \mathrm{min} / 1.73 \mathrm{~m}^{2}$, or on dialysis) to a greater degree than combination therapy of an ACEI (benazepril) plus diuretic (hydrochlorothiazide) in hypertensive patients with high risk cardiovascular events. However, in patients with CKD, more than half of whom had diabetic nephropathy, progression of CKD was similar in the two groups. CKD patients with albuminuria at baseline had a greater reduction in albuminuria in the ACEI plus diuretic group compared with the ACEI plus CCB group. They also observed a reduction in albuminuria in the ACEI plus diuretic group, whereas it increased in the ACEI plus CCB group. These results are in accordance with the GUARD study ${ }^{7}$, which showed treatment with an ACEI (benazepril) plus a diuretic (hydrochlorothiazide) in patients with diabetic nephropathy reduced albuminuria to a greater extent than an ACEI (benazepril) plus CCB (amlodipine). In contrast, eGFR declined more in the ACEI plus diuretic group than in the ACEI plus CCB group. From the findings of these two studies, it remained unclear which combination therapy was more effective in CKD patients.

In this issue, Hayashi et al. ${ }^{8}$ reports very interesting results from subanalysis of renal data of the Japanese Trial to Assess Optimal Systolic Blood Pressure in Elderly Hypertensive patients (JATOS). Elderly hypertensive patients ( $\geqslant 65$ years) were assigned to two systolic target groups (a strict treatment group; $<140 \mathrm{~mm} \mathrm{Hg}$, and a mild treatment group; 140 to $<160 \mathrm{~mm} \mathrm{Hg}$ ) and then treated with T-type CCB efonidipine-based regimens.
The incidence of renal events (a doubling of serum creatinine or end-stage renal disease) did not differ between the strict treatment and mild treatment groups, with the efonidipine base regimen increasing eGFR to the same degree in both groups. An L-type CCB, such as amlodipine, preferentially dilates the afferent glomerular arteriole rather than the efferent arteriole, with this pharmacological effect leading to an increase in intraglomerular pressure and eGFR. However, urinary protein excretion also increases at the same time. ${ }^{9}$ Surprisingly, treatment with the CCB, efonidipine, increased eGFR but also decreased proteinuria. In patients with proteinuria at baseline, proteinuria disappeared in $60 \%$ of the subjects, although there was no difference in the rate in remission of proteinuria with either the strict or mild regimen. This finding indicates that the decrease in proteinuria was not only dependent on the blood pressurelowering effect. The reduction in proteinuria caused by efonidipine may be because of the T-type CCB dilating both the efferent and afferent glomerular arterioles. ${ }^{10,11}$ As a consequence, efonidipine may be expected to have a long term reno-protective effect.

Hayashi and coworkers also reported a high incidence of cardiovascular events in subjects with an eGFR $<60 \mathrm{ml} / \mathrm{min} / 1.73 \mathrm{~m}^{2}$ and proteinuria at baseline and sustained proteinuria at the end of the study. This cardio-renal continuum has also been reported in Japanese elderly hypertensive patients. The inhibitor of the rennin-angiotensin system is recommended as a first line therapy for hypertensive patients with CKD, especially those with proteinuria and efonidipine can be added to that as a good option when combination therapy is needed. 
1 Levey AS, Eckardt KU, Tsukamoto Y, Levin A, Coresh J, Rossert J, De Zeeuw D, Hostetter TH, Lameire N Eknoyan G. Definition and classification of chronic kidney disease: a position statement from Kidney Disease: Improving Global Outcomes (KDIGO). Kidney Int 2005; 67: 2089-2100.

2 Kannel WB, Stampfer MJ, Castelli WP, Verter J. The prognostic significance of proteinuria: the Framingham study. Am Heart J 1984; 108: 1347-1352.

3 Sarnak MJ, Levey AS, Schoolwerth AC, Coresh J, Culleton B, Hamm LL, McCullough PA, Kasiske BL, Kelepouris E, Klag MJ, Parfrey P, Pfeffer M, Raij L, Spinosa DJ, Wilson PW, American Heart Association Councils on Kidney in Cardiovascular Disease, High Blood Pressure Research, Clinical Cardiology, and Epidemiology and Prevention. Kidney disease as a risk factor for development of cardiovascular disease: a statement from the American Heart Association Councils on Kidney in Cardiovascular Disease, High Blood Pressure Research, Clinical Cardiology, and Epidemiology and Prevention. Circulation 2003; 108: 2154-2169.

4 Ninomiya T, Kiyohara Y, Kubo M, Tanizaki Y, Doi $Y$, Okubo K, Wakugawa Y, Hata J, Oishi Y, Shikata K,
Yonemoto K, Hirakata H, lida M. Chronic kidney disease and cardiovascular disease in a general Japanese population: the Hisayama Study. Kidney Int 2005; 68: 228-236.

5 Japanese Society of Hypertension Committee. The Japanese Society of Hypertension Guidelines for the Management of Hypertension (JSH 2009). Hypertens Res 2009; 32: 3-107.

6 Bakrit GL, Sarafidis PA, Weir MR, Dahlöf B, Pitt B, Jamerson K, Velazquez EJ, Staikos-Byrne L, Kelly RY, Shi V, Chiang YT, Weber MA, ACCOMPLISH Trial investigators. Renal outcomes with different fixed-dose combination therapies in patients with hypertension at high risk for cardiovascular events (ACCOMPLISH): a prespecified secondary analysis of a randomized controlled trial. Lancet 2010; 375: 1173-1181.

7 Bakris GL, Toto RD, McCullough PA, Rocha R, Purkayastha D, Davis P, GUARD (Gauging Albuminuria Reduction With Lotrel in Diabetic Patients With Hypertension) Study Investigators. Effects of different ACE inhibitor combinations on albuminuria: results of the GUARD study. Kidney Int 2008; 73: 1303-1309.

8 Hayashi K, Saruta T, Goto Y, Ishii M. Impact of renal function on cardiovascular events in elderly hyperten- sive patients treated with efonidipine. Hypertens Res 2010; 33: 1211-1220.

9 Agodoa LY, Appel L, Bakris GL, Beck G, Bourgoignie J, Briggs JP, Charleston J, Cheek D, Cleveland W, Douglas JG, Douglas M, Dowie D, Faulkner M, Gabriel A, Gassman J, Greene T, Hall Y, Hebert L, Hiremath L, Jamerson K, Johnson CJ, Kopple J, Kusek J, Lash J, Lea J, Lewis JB, Lipkowitz M, Massry S, Middleton J, Miller III ER, Norris K, O'Connor D, Ojo A, Phillips RA, Pogue V, Rahman M, Randall OS, Rostand S, Schulman G, Smith W, Thornley-Brown D, Tisher CC, Toto RD, Wright Jr JT, Xu S, African American Study of Kidney Disease and Hypertension (AASK) Study Group. Effect of ramipril vs amlodipine on renal outcome in hypertensive nephrosclerosis: a randomized controlled trial. JAMA 2001; 285: 2719-2728.

10 Hayashi K, Nagahama T, Oka K, Epstein M, Saruta T. Disparate effects of calcium antagonists on renal microcirculation. Hypertens Res 1996; 19: 31-36.

11 Ozawa Y, Hayashi K, Nagahama T, Fujiwara K, Saruta T. Effect of T-type selective calcium antagonist on renal microcirculation: studies in the isolated perfused hydronephrotic kidney. Hypertension 2001; 38 : 343-347. 